\title{
EDITOR'S NOTE: THIRD WORLD OR GLOBAL SOUTH?
}

\section{Paulo Fagundes Visentini ${ }^{1}$}

With the end of the bipolar system, the academic mainstream of International Relations considered that the concept of Third World had no longer operational or theoretical consistency, given that the countries of the Second World (socialist) were converting themselves into "Market Democracies". The expression Third World was coined by French demographer Alfred Sauvy, in I952, as an analogy to the Third State (people without privileges) from the time of the French Revolution.

The Third World encompassed very distinct nations, but they had in common the fact that they had constituted the colonial or semi-colonial periphery. In addition to objective factors such as an expanding and young population and abundant natural resources, their limited level of development pointed to potential economic expansion and for the articulation of political organizations such as the Movement of Non-Aligned Countries. There was the pursuit of development, anti-colonialist and neutralist ideology, as well as the rejection of accession to military blocs and to the great power politics.

Rather than creating a theoretical fad, the introduction of the Global South concept represented a strategy to depoliticize the meaning of Third Worldism. The Global South is not defined by a positive agenda, but by a negative one because, after all, the North is also global, is it not? Thus, according to the new concept there is no sense in the existence of the Group of 77 or the Non-Aligned Movement. All Southern States would be diluted in globalization, and the largest nations would enjoy the status of "emerging markets."

However, the unequal and combined development process, which is part of the essence of the world capitalist system, continued to follow its

I Editor, Titular Professor of International Relations at Universidade Federal do Rio Grande do Sul (UFRGS). Coordinator of the Brazilian Centre for Strategy \& International Relations (NERINT). E-mail: paulovi@ufrgs.br 
course. Soon after, initiatives such as the IBSA Dialogue Forum, the autonomist and developmental diplomacy of the BRICS (with Russia and China forming a new Second World) and other variable geometry coalitions came into place. The Non-Aligned Movement continued existing (and growing) and the 6oth anniversary of the Bandung Conference demonstrated the importance and continuity of the Third Worldism.

Hence the constant criticism of any reference to the movements linked to South-South Cooperation, the BRICS and the minimal questioning of international rules defined by the great powers of the North Atlantic. There is a crisis and globalization, in order to sustain itself as a system, needs to avoid any misconduct of other States, no matter how small. Politicians, military, diplomats, journalists and academics are confronted with this situation fostered by the "international community" (powers that speak on behalf of others).

Despite the denial of the importance of the regions that compose the Third World / Global South, what is observed in them is an increasingly fierce strategic dispute, which in a previous edition was called "Economic War". In Latin America the progressive regimes that emerged in this century are under strong pressure from powers and international organizations. Africa has become a playing field between governments and Euro-US companies on the one hand, and the Chinese and other members of the BRICS on the other. In the Middle East, the armed conflict reached the size of a general war, while in Asia an attempt to form political, military and economic blocs can be observed.

So, this issue of the Austral journal is dedicated to those regions, including an article by Professor Beatriz Bissio, which was one of the editors of the famous Third World Journal. It is very important for the new generations of internationalist scholars to be aware of concreteness, activities and complexities of Third World initiatives consecrated by the UN, such as the New International Economic Order and New World Information and Communication Order.

\section{$* * * *$}

We thank the Office of Research of the Deanship of UFRGS, which, through the Support Program for Journal Editing (PAEP), supported the translation, editing and printing of the Journal as well as the whole team that worked on the editing and translation, in particular assistant editors Vitória Gonzalez and Isadora Coutinho and the designer Tiago Oliveira Baldasso. We are also grateful to the Professor Cristina Soreanu Pecequilo for the revision of the English versions. 